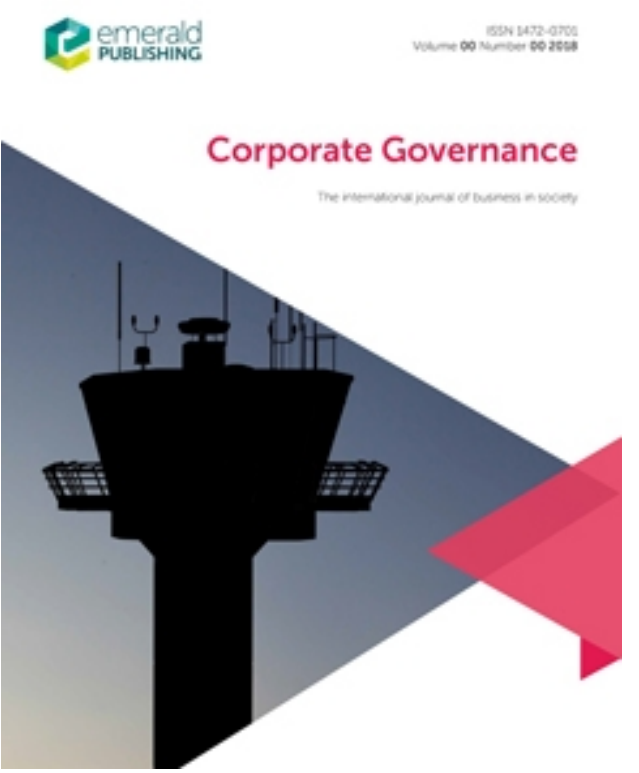

\title{
Corporate Social Responsibility Strategies in Nigeria: A Tinged Shareholder Model
}

\begin{tabular}{|r|l|}
\hline Journal: & Corporate Governance \\
\hline Manuscript ID & CG-12-2019-0389.R4 \\
\hline Manuscript Type: & Original Article \\
\hline Keywords: & $\begin{array}{l}\text { Corporate Social Responsibility, Case Studies, Corporate responsibility, } \\
\text { Shareholder primacy, Tinged shareholder model, Corporate externalities }\end{array}$ \\
\hline \multicolumn{2}{|l}{} \\
\hline
\end{tabular}

\section{SCHOLARONE \\ Manuscripts}




\title{
Corporate Social Responsibility Strategies in Nigeria: A Tinged Shareholder Model
}

\begin{abstract}
Purpose: This paper examines two important issues in CSR scholarship. First, the study problematizes corporate social responsibility (CSR) as a form of self-regulation. Second, the research explores how CSR strategies can enable firms to recognise and internalise their externalities while preserving shareholder value.
\end{abstract}

Design/Methodology: This study employs a tinged shareholder model to understand the interactions between an organisation's CSR approach and the effect of relevant externalities on its CSR outcomes. In doing this, we adopt the case study qualitative methodology, relying on data from one Fidelity Bank, Nigeria.

Findings: By articulating a tripodal thematic model - governance of externalities in the economy, governance of externalities in the social system and governance of externalities in the environment, this paper demonstrates how an effective combination of these themes triggers the emergence of a robust CSR culture in an organisation.

Research Implications: This research advances our understanding of the implication of internalising externalities in the CSR literature in a relatively under-researched context Nigeria.

Originality: Our data allows us to present a governance model that will enable managers to focus on their overarching objective of shareholder value without the challenges of pursuing multiple and sometimes conflicting goals that typically create negative impacts to nonshareholding stakeholders.

Keywords: Shareholder primacy; Corporate Social Responsibility (CSR); Corporate externalities; Nigeria; Tinged shareholder theory

\section{Introduction}

The growing traction of corporate social responsibility (CSR) derives from the long-term benefits it offers to firms and societies (Moir, 2001; McWilliams and Siegel, 2001). While these gains underpin the shareholder and stakeholder discourse in the CSR literature (Jamali, 2008), businesses that ignore CSR run a risk to their bottom-line and reputation, as poor social and environmental practices trigger severe negative impacts on firm profitability (Adegbite et al., 2019). The shareholder-stakeholder controversy is fuelled by the growing awareness of customers who, due to increased access to information, engage with companies that are not only ethical but also sympathetic to environmental and societal causes (Rao et al., 2012). However, myriad of problems relating to the operating environments of firms (Amaeshi et al., 2016), and the contestation that profit maximisation as the primary reason for corporate existence can no longer hold good (Jensen, 2001), have intensified consciousness in the CSR concept (Johnston et al., 2019).

Given the many challenges confronting CSR, this paper seeks to draw attention to the voluntary (self) governance role of CSR, which could be effective in curtailing the excesses of the shareholder model of the firm. These excesses relate to the firm's ability to create enormous negative corporate externalities (Cuervo-Cazurra, 2018; Chen et al., 2018; Chen et al., 2020). For instance, the 2010 BP oil spill disaster in the Gulf of Mexico (Heflin and Wallace, 2017), 
and the near-collapse of the global financial system in 2008/2009 (Mishkin, 2011; Lauesen, 2013) highlight the enormous and far-reaching consequences of negative corporate externalities on society. While the harmful effects of the BP oil disaster were borne by wildlife, small businesses, and people's livelihoods; taxpayers (who prevented the banks from collapse) and investors (who lost their investments and earnings) endured substantial losses during the global financial recession, attributed to banks in shareholder-oriented economies. In both cases, there were negative externalities experienced by stakeholders that had no input in creating the problems. As such, both cases raise concerns about economic actors and their leaning towards shareholder primacy (von Kriegstein, 2016) without responsibility for externalities. Besides, there are various instances of unethical pursuit for profit - a proxy for shareholder value which dominates the shareholder model of the firm (Davies, 2002).

While criticisms of the shareholder model thrive (Lazonick, 2010; Baden and Harwood, 2013; Queen, 2015), this paper focuses predominantly on the issue of externalities. Externalities create a governance challenge given the inability of the state and other governance actors to curtail the excesses of firms due to information asymmetry (Healy and Palepu, 2001; Cui et al., 2018). Arguably, one way to address this challenge is through self-regulation, which includes CSR as a mechanism for the governance of externalities (Crouch, 2006). Windsor (2006) describes this approach as the 'expansive public policy' role of CSR. This governance perspective of CSR, often neglected in the literature and practice (Windsor, 2006; Amaeshi et al., 2013), is particularly crucial for firms operating in environments characterised by weak public regulatory enforcement and governance. Such business environments often offer more incentives for businesses to externalise negative impacts than to behave responsibly (Bakre, 2007; Amaeshi et al., 2016).

Furthermore, the prevalence of externalised social/environmental costs is intense in weak institutional contexts owing to reasons that include corruption, extreme competition, the weak rule of law, inefficient markets, etc. (Campbell, 2007; Kaufmann et al., 2008; Adegbite, 2015). In such contexts, the nature of market competition, for example, is exposed to more negative than positive externalities, given the 'free-riding' disincentives associated with the latter. In turn, 'free-riding' encourages a race to the bottom-line and promotes the pursuit of self-interest at the expense of others' interests (Campbell, 2007). This is the situation in developing economies, such as Nigeria.

Drawing from the unique case of Fidelity Bank ${ }^{1}$, Nigeria, and guided by the Global Reporting Initiative (GRI) criteria ${ }^{2}$ for financial institutions in relation to externalities, we explore the CSR strategies that Fidelity Bank utilises in addressing potential externalities to different stakeholder groups. Our approach encapsulates the peculiar dynamics of CSR in the banking sector (Macey and O'Hara, 2003; Herzig and Moon, 2013) and reflects peculiar perspectives of governance and management in sub-Saharan Africa (SenyKan, Aptisa and Adegbite, 2015). Relying on a qualitative approach that includes in-depth interviews, focus group discussions and documentary analysis (see also, Archel et al., 2011), we contribute to the literature by presenting CSR as a governance mechanism for addressing the excesses of the shareholder value model of the firm. Our discussions depart from the mainstream characterisations of CSR,

\footnotetext{
${ }^{1}$ Fidelity Bank Plc is a Nigerian bank which began operations in 1988 as a merchant bank and converted to commercial banking in 1999. The bank became a universal bank in 2001. Today, Fidelity Bank is a result of the merger with the former FSB International Bank Plc and Manny Bank Plc in 2005 (Fidelity Bank, 2014; Amaeshi, et.al. 2016).

${ }^{2}$ These criteria include economic (market presence, indirect economic impacts, lending practices), environmental (emissions, effluents and waste, biodiversity, transport) and social considerations (employee practices, human rights, product responsibility, societal responsibility) in relation to externalities (GRI, 2013).
} 
which provide overly broad and possibly unbounded societal responsibilities to managers. Instead, we set a minimum responsibility standard for firms to, at least, internalise the negative externalities, which they generate in the pursuit of shareholder value maximisation (Daudigeos and Valiorgue, 2011).

The rest of this paper is structured as follows: First, we present our theoretical framework and subsequently review the literature on the limitations of shareholder primacy in relation to market failures and corporate externalities, while examining the potential of CSR as a governance mechanism. This allows us to highlight our research agenda and to present our research design and method. Following on, we discuss our data emphasising how CSR can help to address the excesses of the shareholder model, presenting implications for corporate governance, strategy and regulation. Finally, we highlight the paper's contribution to the literature and their implications for future research.

\section{Theoretical Framework: Why Tinged Shareholder Model?}

Shareholder and stakeholder theories have dominated the organisational literature. While stakeholder theory emphasises the social role of firms outside of the framework of purely legal contractual relationships (Moore, 1999), shareholder theory centralises the interests of shareholders, utilising legal and implied contracts that entrench the fiduciary duty of managers. Combining both concepts can enhance firm performance, as the stakeholder model suggests that the fiduciary obligations of directors should extend beyond wealth creation to include benefits in areas of social relationships and quality of life (Fassin, 2008). However, as Moore (1999) contends, neither of these models is universally compelling due partially to the complexity of free-market environments and business behaviours. Therefore, Moore (1999) reasons that it is helpful to concentrate on the connections between both models, proposing a tinged shareholder theory that focuses more on moral duty, virtue, and how corporate activities benefit communities. While von Kriegstein (2016) links the tinged shareholder model to shareholder primacy, the tinged shareholder notion permits directors with fiduciary responsibilities to balance the diverse interests of different stakeholders such as shareholders, employees, customers, among others. Thus, the tinged shareholder notion, according to Langtry (1994), stresses that the activities of firms should emphasise the maximisation of stakeholders' interests, subject not only to legal considerations but also to moral and social commitments.

Moore's (1999) 'tinged shareholder theory' draws attention to the tension between a responsible firm's strategy and corporate governance, which seeks the maximisation of shareholder value within an externally conscious CSR framework. In addressing this tension, Jensen (2001) argues that "those who care about resolving monopoly and externality issues will not succeed if they look to firms to resolve these issues voluntarily." This makes reconciling shareholder value maximisation with an externally conscious CSR a significant challenge, and one can query the incentives for firms to adopt CSR. Jensen (2001) and Kaler (2003) also contend that stakeholder management (and CSR) multiplies the objectives of the firm (incorporating negative externalities), thereby complicating further the focus on shareholder value. This hints at the possibility of tension, given the assumption that achieving one will be at the cost of the other (Kaler, 2003). If this perspective holds, it implies that economic agents can either pursue shareholder value maximisation or voluntary externality reduction, but not both objectives at the same time. Nakpodia and Adegbite (2018) demonstrates how economic agents can steer firm decisions in a preferred direction. 
As a counter perspective, in this paper, we seek to draw attention to the voluntary (self) governance role of $\mathrm{CSR}^{3}$ (Crouch, 2006; Windsor, 2006), reflecting on its usefulness in curtailing the excesses of the shareholder model of the firm. In doing this, we draw on Crouch (2006), who acknowledged that a robust understanding of CSR provides a mechanism for governing corporate externalities. This paper, however, extends Crouch's (2006) ideas, as it also examines the themes of 'recognising' or 'internalising' corporate externalities using CSR. We suggest that the organisation operates in a market where 'pure' profit maximisation may be 'tinged' with some 'moral rights' (Moore, 1999; Kaler, 2003) that can be managed through CSR. As such, relying on the "tinged shareholder theory" proposal in Moore (1999), we argue that in the interplay between the organisation and the market, CSR can be reconciled with shareholder wealth maximisation as rhetoric and as a mythicizing or demythologizing reality (Solomon and Darby, 2005). Moreover, this article indicates that regardless of the criticisms of the shareholder model, there are opportunities to defend and re-articulate the model as a legitimate goal of the firm, as long as it recognises and internalises its externalities (i.e., thirdparty costs) through CSR. In other words, a 'tinged' shareholder theory that encompasses moral rights, where morality ultimately emphasises the good of the firm and its industry. Therefore, by engaging the tinged shareholder model, this paper fills a gap in the literature by examining how CSR can mediate as a governance instrument in the pursuit of shareholder value by organisations in weak institutional contexts.

\subsection{The Pursuit of Shareholder Value and the Governance of its Consequent Externalities: Where does CSR come in?}

The pursuit of shareholder value is typically perceived as the primary purpose of profit-seeking firms (Sharfman, 2014). The importance of profit maximisation to shareholders, in this case, is explained by the positioning of shareholders as a public source of funds in contemporary stockmarket capitalism (Ireland, 2005). They take risks in investing in firms hence they are entitled to a share of the profit generated by firms (Sison, 2007). While this is the central premise of the shareholder view of the firm (or the shareholder wealth maximisation model), the model has been linked to some global economic developments in recent times.

The 2008 global financial crisis is a case in point. One of the initial consequences of the crisis was to re-direct attention to shareholder capitalism, as a mode of economic coordination, and its underpinning philosophy with regards to corporate externalities (Kemper and Martin, 2010). Some critics questioned the sustainability of shareholder capitalism (Gamble, 2009), while others have thought of it as a system that has run out of steam and is facing impending selfdestruction (Laibman, 2002). A major criticism is that a significant part of contemporary capitalism has shifted because of the pursuit of self-interest with the illusion of meeting collective interests through that means. This pursuit of self-interest, perhaps inadvertently, often leads to class struggles, inequality, injustice, poverty, trade imbalances and protectionism (Boltanski and Chiapello, 2001; Chiapello, 2007), which are exacerbated by the current wave of globalisation and its discontents (Stiglitz, 2002). Following its negative consequences, shareholder capitalism is viewed as a constraining force, which privatises profits and externalises losses (Crouch, 2008; 2009).

\footnotetext{
${ }^{3}$ While we suggest CSR as a "private (voluntary) mechanism", we recognise that institutional influences and legitimacy drivers of CSR make CSR less purely voluntary but in some cases a response to external stakeholder pressures and expectations (Yekini et al., 2017). For example, the literature on strategic CSR considers CSR as an important constituent of the firm's ability to retain stakeholder support which may impact on profits and eventual shareholder value (Chiu and Sharfman 2011; Udayasankar 2008).
} 
These criticisms are not new. Shareholder capitalism has always had its staunch critics in history (Marx, 1867; Polanyi, 1944). More recently, Jack Welsh, former CEO of General Electric, opined that "on the face of it, shareholder value is the dumbest idea in the world" (The Economist 2010a). These criticisms seem somewhat ironic given that a goal (i.e., maximisation of shareholder wealth) so profoundly entrenched in business is causing the very problem it was intended to address, and the criticisms got louder during the latest global financial crisis (Kramer, 2012). Notwithstanding, while the demise of shareholder capitalism, as we know it today, still comes across as a distant mirage, a critical issue that has received limited attention is how the shareholder model of the firm can reinvent itself and internalise its negative externalities and enhance its positive externalities. This is important as evidence (Galunic, Ertug and Gargiulo, 2012) suggests that firms benefit from embracing this practice. In recent years, there have been initiatives to implement this perspective, for example, impact investing (Agrawal and Hockerts, 2019; Mersland et al., 2020) and social impact reporting (Toppinen and Korhonen-Kurki, 2013) by firms. Also, independent organisations such as the Coalition for Inclusive Capitalism and the Global Alliance for Banking on Values are pushing the narrative of using the corporation for sustainable development.

Unsurprisingly, however, firms rarely internalise the full socio-environmental costs associated with the production of goods and services (Unerman et al., 2018). This may, therefore, imply some adverse and 'unjust' spill-over effects (negative externalities), which are not recognised by the market. The inability of markets to adequately reflect such costs is technically referred to as 'market failure.' In this regard, markets fail to ensure the most efficient or most beneficial allocation of resources, thereby giving rise to externalities. Previous works have discussed approaches to internalising negative externalities, which amongst others, include regulation, social pressures, enhanced or augmented market mechanisms, and self-regulation (Tirole 2005). While the focus has mainly been on negative corporate externalities, we recognise that firms also have positive externalities/spill-overs on multiple stakeholders in their pursuit of shareholder value, as represented in Figure 1. For example, the continued existence and profitability of the private sector helps to keep employees in jobs and facilitates firms' ability to employ far more than the government.

Insert Figure 1 about here

Furthermore, prosperous companies (especially large ones) keep other companies (especially smaller ones, such as suppliers) in business. Also, governments across the world derive significant corporate taxes, which they allocate to benefit multiple stakeholders in terms of providing health care, security, infrastructure, and a better quality of life. Another example of positive corporate externalities includes the salaries of employees that directly or indirectly impact positively on the local economy (i.e., multiplier effects). It could also be the extra cost voluntarily incurred by a producer to go beyond the minimum expected by regulation (Adegbite, 2012), or the provision of education and other social infrastructure by firms through philanthropic or other corporate citizenship activities (Amaeshi et al., 2013; Amaeshi, 2010). However, given that the negative externalities often generate the fiercest criticisms against the shareholder model of the firm, we present an opportunity to address these negative externalities. This is where we investigate the role of CSR as a form of self-regulation.

According to Campbell (2007: 951), CSR - as a form of self-regulation - is "not knowingly do(ing) anything that could harm...stakeholders... (and) if corporations do cause harm to their 
stakeholders, they must then rectify it whenever the harm is discovered and brought to their attention." This governance view of CSR, also, comes through in Amaeshi et al.'s (2016, pp. 148) definition of CSR in developing countries (with weak institutional environments) "...as the voluntary reduction of negative corporate externalities and the commitment to enhance positive externalities by addressing social problems and filling institutional voids sustainably" (emphasis in the original). This encompassing view is central to the understanding of CSR as a mechanism for governing corporate externalities (Crouch, 2006). In that regard, while firms are not responsible for solving all societal issues, especially those that they have no input in causing, they should address the problems that they create, and especially the socioenvironmental concerns of their business operations (Kanter, 2011). This is especially important in developing countries, such as Nigeria, marred by weak regulation and corruption (Okike et al., 2015; Agyei-Mensah, 2017; Nakpodia et al., 2018). It is from this perspective that we explore how CSR can represent a smarter, voluntary, and complementary (and in some cases as an alternative) governance instrument to the hitherto existing governance mechanisms of corporate externalities. Our exploration is guided by the question:

How can CSR strategies enable firms to recognise and internalise their externalities, while preserving shareholder value, especially in weak institutional contexts (Nigeria)?

Nigeria is Africa's second-largest economy due to its vast earnings from oil exports. However, many Nigerians live in poverty amidst weak infrastructure, insecurity, poor governance, weak public sector, and corruption, which allows tax evasion, corporate exploitation, abuse of employment rights, environmental degradation and other corporate externalities (Kaufmann et al., 2008; Amaeshi et al., 2016; Bakre, 2007). As a result, firms can behave illegally and immorally without significant consequences, thus incentivising companies to prioritise shareholder wealth maximisation even where there are direct negative externalities to society. The burgeoning literature on corporate social irresponsibility (e.g., Lange and Washburn, 2012; Hawn, 2009; Murphy and Schlegelmilch, 2013; Sweetin et al., 2013) highlights some of these trends and their externalised social/environmental costs in weak institutional contexts (Amaeshi et al., 2016; Adegbite and Nakajima, 2011). It is from this peculiar socio-economic context that we explore our research question using a single case study of Fidelity Bank. Locating our study in such a unique institutional context helps us to gain insights into how the various externalised social costs can be internalised while still pursuing shareholder wealth.

Besides, the Nigerian banking sector is particularly useful to our research question, because the literature on shareholder primacy has predominantly treated the corporate scenery as a homogenous entity with limited attention paid to sectoral peculiarities and how these shape the notion of firms' externalities and the means to minimise them (Bonin et al., 2005; Iannotta et al., 2007; Adegbite, 2012). While firms in all sectors should internalise their negative externalities, the banking sector is unique (Herzig and Moon, 2013). It has peculiar challenges due to other financial risk-bearers of the 'banking activity' apart from shareholders, especially the depositors and the government, both of whom require the vitality and longevity of the banking system (Adegbite, 2012). As a result, while the externalities from banking can be positive (including contributions to economic development and external economies of scale between institutions), problems relating to information asymmetry, free riding as well as the systemic risk and its contagious effects in the broader economy make banking particularly susceptible to negative externalities (Jamali and Karam, 2018). Moreover, the larger a bank gets, the less likely the government will allow it to fail, thus shielding it from potential losses as such larger banks tend to generate significant social costs and negative externalities that encourage them to take on too much risk (The Economist, 2010b). It is therefore pertinent to 
examine how banks voluntarily internalise the externalities of their activities, particularly in the environment of weak regulation (Adegbite, 2012).

\section{Research Methodology}

This study is part of a larger research project which critically examined CSR in weak institutional settings, which informs the extensive methodological approach adopted (see Amaeshi, Adegbite and Rajwani, 2016). The nature of the research question necessitated a qualitative research design to enable us to focus on a micro-level firm analysis. ${ }^{4}$ This helped us in understanding how CSR can help internalise negative corporate externalities in a weak institutional context. We followed a single case study approach (Eisenhardt, 1989; Bondy, 2008; Gaya and Smith, 2016; Bell et al., 2018) to contextualise the rich descriptions of how CSR initiatives were enacted in a weak regulatory context. We explored the processes of "how" CSR serves as a private governance of externalities (Yin, 2014; Bondy 2008). Our case study approach helped to investigate our research question, which was related to a "complex and dynamic phenomena where many variables, including variables that are not quantifiable, are involved.... actual practices, including the details of significant activities that may be ordinary, unusual, or infrequent [and] phenomena in which the context is crucial because the context affects the phenomena being studied, and where the phenomena may also interact with and influence its context" (Cooper and Morgan, 2008, pp. 160). Unlike other approaches such as cross-sectional analysis of companies, our focus on a single case study was appropriate and offered a very intensive investigation into the dynamics that shape how CSR addresses corporate externalities within the selected organisation (Eisenhardt, 1989). We focused on a limited and specific organisational setting and examined the CSR activities and experiences of the chosen organisation as well as the context in which they occur.

\subsection{The Case Study}

We relied on leading literature on qualitative research (Cooper and Morgan, 2008; Yin, 2014) to guide us in the criteria for selecting a suitable case study. Given that our research question focuses on how local firms use CSR to internalise externalities, an appropriate case for an investigation such as ours should be a local company with no international affiliation to capture better the institutional context within which our research finds relevance. We argue that such a case study should have been recognised for their outstanding contribution to a sustainable business environment. Fidelity Bank Plc fully met this criterion and was chosen as our case study because of its exceptional responsible business practices (at the Nigeria CSR Awards, $2013,2014)$ in an environment with minimal incentives to internalise third party costs. Fidelity Bank operates in the major commercial centres of Nigeria and is reputed for integrity, professionalism, quality, the stability of its management, and staff training (Fidelity Bank, 2014; Amaeshi et al., 2016). Fidelity Bank has been locally and internationally recognised for its CSR (through her Helping Hands Programme) values, innovations, and practices that directly impact the stakeholders in the various communities in which they do business (Amaeshi et al., 2016). Fidelity Bank serves as an outlier - a deviation from the norm - and thus presents itself as an appropriate 'black swan' (Flyvbjerg, 2006; Yin, 2014) and the 'logic of a situation' (Gibbert, 2006, pp. 46) for our study. Moreover, the bank is an entirely local (Nigerian) bank, with no international operations, thus enabling an examination of how CSR can help domestic firms internalise negative corporate externalities despite the challenges of their institutional contexts (see Okpara, 2011).

\footnotetext{
${ }^{4}$ This study is part of a larger research project which critically examined CSR in Nigeria.
} 


\subsection{Data Collection}

Data collection spanned 17 months (Sept 2013 - February 2015) and was driven by a purposive sampling technique (Eisenhardt, 1989). The process began with the researchers drawing insights from in-depth interviews using semi-structured questions with the principal CSR officers at Fidelity Bank. This is in line with the extant research on CSR (Archel et al.. 2011; Amaeshi et al., 2016) within institutional contexts, where micro institutional factors such as personal beliefs, religions and macro institutional factors such as the socio-political system play a role in the understanding of, and motivation for CSR. Interviews were held with the Head of CSR and Community Relations (and also, the Coordinator, Fidelity CSR (Helping Hand) Programme) and the Head of Marketing Communications at Fidelity Bank in the last quarter of $2013^{5}$. The respondents were sent an interview guide to facilitate their preparation and to ensure cooperation (Lynn et al., 1998). This was in line with previous studies (see, for example, Amaeshi et al., 2016; Hendry et al., 2007). Interviews lasted around 70 minutes.

The data collection process also included a focus group session in June 2014 and interviews in February 2015. Participants were principal CSR officers, including senior management staff. The recent data collection efforts helped to compare and gather further evidence on the themes that emerged from the prior interview data. The focus group session had 9 members, and the following interviews were conducted with 3 senior CSR officers. This small number of the focus group participants helped to increase the efficiency of the focus group session and enabled members to freely discuss CSR in Nigeria (Ewings et al., 2008). Participants were drawn from different backgrounds and functions, to ensure representativeness and diversity of perspectives. More importantly, discussions were tape-recorded and took around 109 minutes in the focus group session and 60 minutes in the interview sessions.

\subsection{Data Analysis}

We triangulated the interviews and focus group data with documentary evidence and archival data, which helped to contextualise our research in the Nigerian banking industry setting appropriately. This also ensured we enhanced validity and reliability. We also shared our findings with the senior executives at Fidelity Bank to see if our analysis tracked their reality. As with most inductive studies based on single in-depth cases, the first phase of the data analysis was a pilot, which constituted some familiarisation and sense-making of the data on CSR in the Nigerian banking sector. This suggested some patterns around how CSR can help internalise negative corporate externalities in weak institutional environments. This enabled the development of a coding scheme around emergent themes. We used raw extracts from the interviews and focus group data in discussing the themes that emerged from the data (Saunders et al., 2015). The interpretation of the data suggested some patterns around the governance role of CSR in Fidelity Bank.

While the methodology adopted in the study pays sufficient attention to the Nigerian sociopolitical, economic and cultural context, we utilise a very critical lens in examining our data in relation to the depiction of Fidelity Bank's corporate behaviour. As a result, we avoided an over-reliance on the interview/focus group data from Fidelity Bank's management, making sure we critically examined contradictory evidence which raised queries about Fidelity Bank's CSR practices, which may have been missed during data collection, i.e., interviews and focus group. For example, our analysis paid attention to some criticisms of Nigerian banks, possibly

\footnotetext{
${ }^{5}$ Both interview respondents lead the CSR activities of the company and are responsible for formulating its strategy, in direct working relationship with the CEO.
} 
including Fidelity Bank, with regards to crony capitalism, money laundering, amongst other unethical behaviours. As a result, our focus on Fidelity Bank does not present the bank as entirely free of irresponsibility. The bank offers a valuable case study in the Nigerian context, given its extensive CSR activities orchestrated specifically as a voluntary governance system, which outweighs the criticisms of the bank. Despite our triangulated data, our qualitative approach can be predisposed to respondents' position bias, which may influence them to overreport past events and strategies or present themselves and Fidelity Bank in a socially desirable image (Miller et al., 1997), especially at the expense of others ${ }^{6}$. Thus, to minimise these effects, we ensured that the data respondents satisfied the purposive sampling requirement of competence and experience (Hughes and Preski, 1997) and that the principal CSR officers could describe the CSR environment more competently than other members of the firm (Payne and Mansfield, 1973).

The texts generated from our data sources were analysed with NVivo 10, and the inter-coder reliability was well over $85 \%$. We conducted a timeline to understand the "how" question by coding interview and focus group data as well as documents, including 15-year documentation of Fidelity Bank's CSR activities. With the vast amounts of primary data, records from news' reports, company reports, and press releases, we developed codes to frame the development of theoretical logics from our data. After that, we used quotes and observations to create an interpretive model to answer our research question and to inform our critical and contextsensitive analysis. The next section presents our findings.

\section{Findings}

In presenting our findings, we are guided by the Global Reporting Initiative (GRI) criteria for financial institutions, which provide a useful framework in analysing the firm's impact and CSR strategies for crucial sustainability areas. While we note some positive externalities, we focus mainly on the likely adverse economic, environmental, and social externalities which a bank can create in weak institutional contexts and how Fidelity Bank voluntarily uses CSR to minimise/internalise them while pursuing shareholder value. As our discussions will reveal, a single CSR strategy/practice can address externalities in multiple spaces.

\subsection{Governance of Externalities in the Economy}

Here we focus on the economic governance of externalities through market presence, indirect economic impacts, and the lending practices of Fidelity Bank. The case study of Fidelity Bank reveals that the contemporary firm, even as the quintessential expression of capitalist entrepreneurship, does not have to be characteristically skewed towards opportunity 'exploitation.' This quest for exploitation, which is anchored, fundamentally, on self-interest, in turn, strives to annihilate the interests of other parties with a stake in the firm. In such instances, the capitalist entrepreneurial firm has enormous propensity and power to destroy (Bakan, 2004). It is this destructive ability of the modern firm that has lured a lot of criticisms to it. In preventing this, Fidelity Bank aims to give its “...business a human face. That is what we do at Fidelity... apart from the desire to make profit" (Focus group participant). The bank does this by proactively and voluntarily enhancing its positive impacts and minimising negative consequences in the economy, as illustrated below:

\footnotetext{
${ }^{6}$ This presents an opportunity for future research in this space to adopt a combination of other data collection instruments which are less prone to bias.
} 
Banks ought to be responsible to society by doing well, given our role in the economy. In terms of banking impacts, we warehouse people's funds. Depositors want their money to be safe. In addition to that, we are responsible to society by ensuring we lend to the industry and grow the economy. Given Nigeria's over-dependence on oil, we play a significant role in the diversification of the economy by proactively lending to the agricultural sector and engineering sector, in particular. (Interview with a CSR ambassador)

Furthermore, Fidelity Bank "works to ensure economic growth by supporting small scale business growth and entrepreneurship" (Interview with a CSR ambassador). Small scale business financing is another voluntary CSR practice that leads to job creation and poverty reduction. Job creation is a positive externality while poverty reduction is an attempt to minimise some of the negative externalities of a dominant corporate fixation on shareholder value maximization in a country such as Nigeria, where the purchase of government bonds and lending to large (oil and gas) businesses constitute the predominant banking activity (IMF, 2013). While these activities are perceived as less risky, the externality they create is the unavailability of lendable funds to small businesses, which, in turn, creates unemployment and economic stagnancy, especially in the non-oil sectors.

We lend to small businesses, not just the oil and gas sector. We lend to the small-scale tailor, for example. (Interview with a CSR ambassador)

We also went as far as doing social banking. For example, we had a rice farm in Abakaliki [a rural city in the South East region of Nigeria]...the focus of the country/government then was to stop rice importation; so the bank partnered with the rice farm to get it to run smoothly through loans, which are not excruciating, to help their production capacity (Focus Group Respondent).

Also, in the absence of active loan markets, as is the case in Nigeria, the need to provide access to finance to the excluded and the hard to reach, has led to an increasing focus on financial inclusion, as a solution, by the financial services sector (Amaeshi et al., 2016). Through CSR, Fidelity Bank encourages the provision and access to finance by poorer members of the population, such as subsistence farmers and artisans.

Fidelity Bank's mission is to make financial services easy and accessible. Execution of this mission connects us with the goals of sustainable economic development and poverty reduction.... This way, we contribute to ensuring that the costs of economic development do not fall disproportionately on those who are poor or vulnerable (Fidelity Bank website, June 2014).

Social banking by Fidelity Bank helps to reduce externalities of banking activities, arising from the need to focus on more high-net-worth individuals and corporate customers to maximise profit. Furthermore, it costs more to provide banking services to more impoverished and uneducated members of the population, who are unable to utilise the majority of the technology-based personal banking services, thereby requiring direct (often costly) and frequent banking services. As a result, this activity should not merely be regarded as a good business decision (providing services to unserved or underserved customers), but a responsible business practice, which sheds light on how CSR is enacted at Fidelity Bank to minimise negative and enhance positive economic impacts, respectively.

We engaged the unbanked people. Looking at the people at the bottom of the pyramid... who are normally excluded from banking activities...we ... bear the cost of some of our 
staff going to them to conduct banking activities in their markets. We do door to door banking with them; we pick up their deposits and credit their accounts through POS. The cost of these is internalised; we do not charge customers for it. These customers are usually poor (Interview with a CSR ambassador)

However, what is the extent to which these complement the pursuit of shareholder value maximisation in the bank? According to a CSR ambassador, in an interview:

As responsible firms, banks give returns to shareholders, but we are also responsible to society. The way I see it is that our role to shareholders does not mean we cannot be responsible to society. We are making profits in such a way that it does not create any adverse effect on our stakeholders and community. We create value for shareholders by being responsible to the environment in which we operate. We make profit responsibly. We can do both by giving back to society. That is why you have CSR (Interview with a CSR ambassador)

Stakeholders' happiness is compatible with shareholders' happiness. You can do both, and we do both" (Interview with a CSR ambassador).

Our data, in the main, suggest that shareholder wealth maximisation is compatible with stakeholder benefits, and the former is only sustainable with the latter. In many instances, CSR further promotes shareholder value creation. For example, social banking, through bank lending programmes, has helped entrepreneurs to grow and expand their businesses. Consequently, they have remained loyal customers (Head of CSR). CSR, in this manner, enhances the reputation of Fidelity Bank and contributes to shareholder value. This is consistent with the literature on strategic CSR (Deephouse and Jaskiewicz 2013; DelgadoGarcia et al., 2010). Besides, inclusive lending to small scale businesses and other financial strategies not only contributes to a more robust economy, which is beneficial, but Fidelity Bank can benefit more specifically from many loyal customers, as reflected in the significant growth of the bank's customer base in the last decade.

When we lend to small businesses, and they thrive, they become bigger and employ more people, thereby improving the economy. This is what success means for us.... We need a strong economy to thrive as a business (Interview with a CSR ambassador)

\subsection{Governance of Externalities in the Social System}

Further to the consideration of economic externalities, Fidelity Bank uses CSR in minimising social costs through its product responsibility, societal responsibility/investment programmes and employee practices. On product responsibility, while social banking addresses economic externalities, by aiding inclusiveness at the bottom of the pyramid, it remains a social intervention to alleviate poverty. As mentioned earlier, this is an instance where a single CSR practice addresses externality in multiple spaces. Furthermore, by inculcating CSR in Fidelity Bank's activities, the bank can minimise harm to stakeholders and is able to meet diverse human needs especially in critical areas through the "helping hands ambassadors" (Head of Marketing). The "helping hands ambassadors," which is the bank's social investment programme, involves members in all branches, including very senior management staff, who encourage staff members to imbibe such ethos. While there are neither performance incentives for employees to engage in CSR nor penalties for those who do not engage, CSR has been built into the corporate culture of the firm through voluntary participation. This allows Fidelity Bank to enhance the quality of life of others indirectly affected by banking activities in the local communities where the bank operates. In addition to addressing local community needs, 
CSR at Fidelity Bank “...is a channel by which we get those things government are not giving to the people to them" (Focus Group Respondent). The bank does this by:

... bridging those gaps in society, not just because they are our customers, but because it is the right thing to do. We need to affect our society positively. Let it be said that Fidelity, in its existence, made sure that children who did not have access to education are provided such access based on our projects; ... that the girl child who is marginalised has got her right standing in the society through our efforts on educational financing. For example, we go to schools where there are dilapidated facilities, and we refurbish them; give them facilities such as computers. We are change agents. We are addressing the neglect of government (Focus Group Respondent).

We go to motherless babies' homes. We support the government. The government cannot do everything. We go to government hospitals. We do not go the prosperous areas such as Lekki [a suburb in Lagos], where rich people already give to the motherless baby homes there; we go to the downtrodden communities such as Ajegunle and Badia [both are poor neighbourhoods in Lagos] to concentrate our interventions (Focus Group Respondent).

Fidelity Bank also seeks to make positive impacts on employees. Given the weak employment laws in Nigeria and the regular practice of "employment-at-will," laying off staff usually constitutes a negative externality in such institutional contexts where there is no active external labour market. As our data suggest, CSR - as a private governance of externalities - enables firms to reasonably desist from layoffs when external labour markets are inefficient or during periods of economic recession. Employee welfare and job security remain an integral part of Fidelity Bank's CSR culture.

We also pay attention to our employees, their pay, and work-life balance. For example, even though there is a policy that you do not get paid if you get pregnant when you join the company, we relax such rules here to promote family life balance. We have won the 'best place to work' award and the most 'family-friendly company' for the past 4 years (Focus Group Respondent).

The sense of well-being of the staff is also one of the motivations of our CSR; .... We have done a bank-wide general health check for all workers; .... We had a young man (a staff) who had a son who had a hole in his son's heart; the bank sponsored the surgery abroad (Head of CSR).

I have worked for Fidelity for more than 10 years, and we stick to normal working hours in accordance with the law. We switch off our generators nationwide at 6pm, so you cannot be working. We do not push our employees to work excessively to maximise shareholder wealth.... By closing early, they can go home early and have appropriate family-work balance (Interview with a CSR ambassador)

We don't encourage our employees to engage in untoward practices to benefit shareholders. (Interview with a CSR ambassador)

The above quotes are examples of how CSR can be a self-regulatory framework for the governance of externalities towards staff. In ensuring that employees do not pursue shareholder wealth without regard to externalities, Fidelity Bank encourages whistleblowing practices. " $W e$ evaluate our processes regularly to make sure they are responsible. Education, whistleblowing and evaluation is part of our CSR strategy" (Head of CSR). CSR in this context further allows 
for the private governance of externalities in a manner that takes the institutional peculiarity of the business environment into consideration. The bank's CSR in the social space (to the society and employees) also leads to direct employee productivity, commitment, loyalty and retention, which are all linked to firm profitability and shareholder value creation.

\section{Staff members feel the warmth from management (Head of CSR).}

In the long run, for shareholders to be happy, a bank must also make other stakeholders satisfied. If they don't, shareholders may gain in the short term, but they will lose after all" (Interview with a CSR ambassador).

CSR in the local community through the Fidelity Hands programme also contributes to risk management and the security of assets in the bank.

"Every day you hear banks being attacked in Nigeria, but Fidelity bank is never attacked, it is because of the goodwill we receive from our CSR" (Focus group participant).

\subsection{Governance of Externalities in the Environment}

On environmental externalities, we focus on how Fidelity Bank, through CSR, addresses environmental preservation, biodiversity, waste recycling, and carbon emissions. For example, on environmental preservation, a CSR ambassador notes: "We do not lend to those who ... harm the environment" And another says: "we are there also to sustain the environment and make the world a better place for us and the generation unborn." Fidelity Bank has pioneered the use of recycled, biodegradable paper as cash bags, as Nigeria is primarily a cashbased economy (Amaeshi et al., 2016). In relation, the Head of CSR notes as follows: "When people come for large withdrawals, the norm is to use polythene bags; but this impacts negatively on the environment due to carbon foot-printing...but we use biodegradable bags, thus helping the ecosystem. We try to capture the negative impact of our activities on the environment and actively make choices". Fidelity Bank is thus able to internalise the otherwise externality (harm to the environment) arising from banking activities. This also contributes to waste reduction and recycling, which are positive externalities.

On carbon emission, Fidelity provides free bus transportation services for some of its employees. This is particularly useful, given the decadence in transport infrastructure in Nigeria and the traffic problem in Lagos, Nigeria's business capital. While this CSR practice is well within the social (employee) space, it inhabits the realm of the CSR governance of environmental externalities by reducing carbon emission and traffic that would otherwise arise from individual staff members driving their cars to work.

We have over 23 staff buses to provide transport; my colleagues in other banks are so envious of these. (Head of CSR).

Under the governance of social costs, we presented an interview quote which shows that Fidelity Bank prevents externalities to employees by switching off generators and shutting down operations at $6 \mathrm{pm}$. This CSR practice also functions in multiple spaces, as it helps to minimise environmental costs due to emissions. Given Nigeria's weak electricity infrastructure, reducing carbon emission from generators is a severe environmental externality.

By switching our generators off, we reduce our carbon emission and save costs (Interview with a CSR ambassador) 
Fidelity Bank's CSR in the environment also benefits from reputation building, publicity, and a good brand image which contributes to shareholder value. For example, their CSR activity on environmental preservation and beautification, which is a positive externality, attracts "significant marketing benefits and strategic partnerships, which adds to eventual shareholder value" (Focus group participant). In particular, Fidelity Bank works with regional governments (at the State and Local levels) as well as advocacy groups such as the Nigerian Conservation Foundation, and other corporate partners in preserving the environment (Amaeshi et al., 2016).

During the colonial times, there were places mapped out as green areas, but over time our people have abandoned them. So we felt we could take up the challenge of beautifying public places.... We help beautify as part of our focal areas of the environment. We also put our signage in these places (Head of Marketing).

There are also some financial values and cost savings arising from the environmental activities of the bank, as mentioned above, which contribute to the bank's pursuit of shareholder value.

\subsection{Summary}

The drivers of CSR in Fidelity Bank, according to our data, include the firm's sense of morality and stakeholder fairness as well as the quest for social legitimacy (see Amaeshi et al., 2016; Hahn et al., 2015). In summary, our data show how Fidelity Bank creates shareholder value without being skewed towards opportunity 'exploitation,' indicating that shareholder wealth maximisation can co-exist with minimal externalities. In Table 1, we have provided some descriptions/evidence from the Fidelity Bank case study to summarise how CSR, as a private governance of externalities, contributes to shareholder value. The table shows how a CSR practice either prevents negative externalities or creates positive externalities, which directly or indirectly enhance shareholder wealth.

Insert Table 1 about here

\section{Discussions and Implications of Study}

We have attempted to present CSR as a governance tool for internalising negative corporate externalities within a shareholder model logic, and without moving to the stakeholder model. The stakeholder concept argues that managers must cater to and create value for a broader range of organisational stakeholders apart from shareholders (Freeman, 1984). This is not necessarily our proposition. Instead, we argue that the problem with the shareholder model is not shareholder value maximisation, but the way this is pursued, which is frequently by externalising associated costs to other stakeholders.

In that regard, we suggest that the firm's strategy and governance model should remain shareholder focused, but in a way that does not lead to free-riding/externalising of their costs to maximise shareholder wealth. As such, while the firm is focused on shareholder value creation and might not necessarily create value for all stakeholders, it should, also, at least, not create adverse impacts on stakeholders. This is a fundamental difference between our proposed shareholder model and the stakeholder model. In other words, while the stakeholder model says: "do good and do no harm to all stakeholders," our proposed model says: "do 
good to shareholders and at least do no harm to other stakeholders. " Our proposed model does not encourage firms to create value for all stakeholders necessarily. This should help managers to focus on their single objective of shareholder value without the challenges of pursuing multiple and sometimes conflicting goals, albeit without creating negative impacts on nonshareholding stakeholders.

Thus, a fundamental assumption in our perspective of the shareholder model is that managers may be moral and order-oriented, which needs to be balanced with the agency theory's pessimistic view of corporate governance that managers are self-serving (Fama, 1980; Fama and Jensen, 1983). Indeed, while the seminal study of Jensen and Meckling (1976) fostered a fixation on shareholder value, it inspired a movement to get managers to focus on value for shareholders at the expense of other stakeholders (The Economist, 2010a). In our proposed shareholder model, a responsible firm's strategy and corporate governance will entail the maximisation of shareholder value but within a CSR framework that helps to minimise negative externalities and sometimes enhance positive externalities. Relying on the tinged shareholder model, our approach is in line with the revised European Commission definition of CSR as the responsibility of enterprises for their impacts on society (European Commission, 2011).

From a practice perspective, embedding moral alertness in organisational culture through educating managers of the benefits of a CSR framework to govern their externalities, can encourage organisations to internalise costs to other stakeholders, while maximising shareholder value. From a public policy (regulation) perspective, it is a goal for policymakers to ensure that institutions are developed such that firms have the incentives to internalise their externalities, and the disincentives to externalise costs in the pursuit of shareholder value. Policymakers would need to address the perceived disconnect between legal and moral obligations, where the law is considered as the indicator of moral actions, such that companies may behave unethically if the law does not explicitly prohibit such (Stanton-Ife, 2008). In essence, the law should help develop a focus on moral behaviour by organisations that go beyond what the law may or may not say concerning particular situations/externalities. This approach also facilitates the freedom of the consumer, to recognise the shifting of demand, to influence producers' income, and to serve as a framework of accountability (Polanyi, 1944; Gallhofer and Haslam, 1993; Solomon and Darby, 2005).

Despite the merits of CSR, it is not a panacea for all of the negativities of corporate behaviour, but rather its limitations include the difficulty in the comparability of CSR reporting mechanisms, the failure of regulators to oversee CSR failures effectively, the limited rewards for CSR performance, and the challenges of relying on self-regulation and private governance. Indeed, critics of the deliberate attempts of firms to internalise externalities through selfregulation have argued that this has implications for the role of government and public policy (Levy and Newell, 2006; Albareda, 2008; Banerjee, 2009). Therefore, our study does not solve the entire problem of corporate externalities, nor do we claim that CSR can fully recognise and internalise externalities. We also acknowledge the paradoxes inherent in CSR, where one decisive/positive corporate action can also imply negative consequences. An example would be situations where low wages and underemployment are seen as positive and preferred when compared to poverty and unemployment. There are also instances where positive women liberation and gender equality attempts could be perceived as negative impacts on society, based on some cultural (Ringov and Zollo, 2007) and even religious (Nakpodia et al., 2018) norms. It thus follows that we do not claim that our model would completely and comprehensively address these issues, which highlight the importance of multi-stakeholder participation by governments and financial markets across national and political borders. Our approach, nevertheless, suggests a way forward whereby the shareholder model can become 
more oriented towards the attainment of the common good, as this striving will motivate all stakeholders to become committed to its process (Boltanski and Chiapello, 2005; Daudigeos and Valiorgue, 2011). As such, while CSR governance does not present a perfect world or a robust market system, it offers a situation where firms that internalise their externalities are more likely to induce stakeholder contributions as firms that exploit externalities may find it much harder to do so.

In this study, we suggest that the shareholder primacy model of the firm should recognise, in addition to the firm-shareholder relationship, the multiplicity of relationships with other constituencies which the firm needs to exist and to operate successfully. In particular, our data suggest that CSR contributes to sustainable shareholder value, through customers' loyalty, employees' commitment and retention, the local community through the provision of a conducive environment and licences to operate, and the financial markets through reward for brand equity and enhanced reputation (Mahon, 2002; Mallin and Michelon, 2011). In the main, our data suggest that externalising third-party costs is not only out of touch with democratic and free-market principles but is detrimental to the long-term health of companies and the economy as a whole (Kelly, 2003). CSR, as a private governance of externalities, is this paper's attempt to rebuild shareholder capitalism to benefit all. In this regard, while our revised shareholder model is fundamentally different from the stakeholder model, both models are not mutually exclusive and can complement each other. Indeed, the success or failure and sustainability of CSR as a self-regulatory mechanism in practice will depend on its co-existence with other complementary governance mechanisms, such as vibrant civil societies, functioning state, efficient market, and legal institutions. Thus, this responsibility falls not only on corporate leaders as suggested by Banyi et al. (2011) but on all stakeholders because perfect markets possibly do not and cannot exist, and even if they do, cannot regulate what they cannot see.

\section{Contributions and Conclusion}

We have examined a major criticism of the shareholder model of the firm with regard to negative externalities and articulated CSR as a corrective mechanism of this model, employing nuanced qualitative data from a less discussed empirical site - Nigeria. The imperfections of shareholder-oriented capitalism, highlighted in this study, offer a strong reason for CSR to "...provide it with the moral foundations that it lacks, and ...enable it to incorporate justiceenhancing mechanisms whose relevancy it would not otherwise have to acknowledge" (Boltanski and Chiapello 2005, pp. 163). No doubt, it may be argued that changing the status quo in practice as a way of enhancing "moral foundations" may be difficult. However, a way forward is for individual firms to structure how they wish to embed CSR thinking and focus in their organisations. This will go beyond documenting 'CSR' activities, which are frequently presented on websites but include a distinct strategic approach as to how they will move from a clear focus on shareholder wealth maximisation to factoring in externalities and other such public costs.

Insert Figure 2 about here

We present a new shareholder model that shows how an organisation could achieve this reorientation in Figure 2. In this model, a firm's aim to maximise shareholder value within a CSR framework will creatively help in minimising its negative externalities, at least; and could 
occasionally create positive impacts. Our model accepts the essential fundamentals of shareholder value creation, including dispersed ownership, and sound legal protection for shareholders, but without the traditional disregard for externalities. The priority remains to enhance shareholders' value but without directly/indirectly externalising costs to others. Our model is distinct from the stakeholder model, which relies on constructs such as stakeholder management, consensus, balancing of interests, and the maximisation of multiple (often conflicting) interests but links well with the growing notion that fairness and harmony within the whole system of stakeholders are non-negotiable (Freeman et al., 2018; Crane, 2018). Our model has a single objective - to create 'externality-conscious' value to shareholders. This model is not only applicable in the Nigerian setting, where the empirical data for this study is drawn but is malleable in its use in varieties of capitalism. Thus, while our study presents implications for weak institutional contexts where the motivation to externalise costs is higher, it further argues for CSR as a private governance of externalities, even in robust institutional settings where regulation is frequently seen as the only key to ensuring good corporate behaviour.

In proposing CSR as a governance framework for internalising corporate externalities, we are not calling for more regulation, as was the case for the emergence of corporate governance laws and codes in response to past company scandals (Adegbite et al., 2011; Nakpodia et al., 2018). Instead, we present a case for the voluntary adoption by corporations of a governance strategy, which inculcates CSR in its pursuit of shareholder returns. In the face of constant criticisms of the shareholder model of the firm, this study has argued for a framework through which firms can legitimately pursue the provision of returns to shareholders while simultaneously internalising potential negative externalities on other stakeholders arising from this pursuit. Here, firms can achieve higher levels of CSR through the ambidextrous ability to simultaneously pursue shareholder value and internalise externalities. CSR, in this manner, is driven by both instrumental and moral initiatives that compensate and supplement each other (Hahn et al., 2015).

Findings from our study offer both theoretical as well as practice relevance. The tinged shareholder theory provides an alternative lens to investigate the failings of the shareholder concept, thereby allowing us to articulate a robust CSR mechanism for governing the negative externalities associated with the shareholder model. In the practice domain, this understanding helps executives to channel organisational resources to the wealth maximisation goals of shareholders, thereby overcoming the difficulty in balancing numerous and contradictory targets that trigger adverse outcomes on other stakeholder groups. This is evident in Figure 2 as the effective management of negative externalities (human rights abuse, environmental degradation, and others) maximises corporate reputation, community goodwill, among other things, translating subsequently to firm profitability.

This study further contributes to critical perspectives on governance and responsibility of the shareholder-centric character of the contemporary capitalist firm, offering some insights on the role of self-regulation through CSR (Gallhofer and Haslam, 1993). Researchers in the fields of corporate governance and CSR should work on the integration of these two strands of literature. This is because "understanding the behaviour of the corporate organisation requires a deep knowledge of its governance and the factors that determine the distribution of power among corporate managers, shareholders, and directors" (Jensen and Warner 1988, pp. 227). Our study suggests a rethink of this shareholder/owner-centric model through which the corporate agenda of maximising shareholder interests are pursued in a stakeholder responsible way, with CSR serving as the governance framework for this. This framework will also convey information and influence perception, for example, by assuring investors that the company's 
managers will not pursue profits above everything else, but strive to cultivate stakeholder loyalty to a social enterprise brand (Page and Katz, 2012; Uche, Adegbite and Jones, 2016). We further recommend to regulators and the market to recognise and reward firms that incorporate externalities in the pursuit of shareholder interests (Daudigeos and Valiorgue, 2011).

Our study also encourages the need to embed long-term thinking into management, particularly in an environment where executive management tenure is short, and investors take a short-term focus on returns on investment. In particular, investments in CSR should not be seen from a short-term view. One of the limitations of the existing literature is how financial performance and CSR interact with the notion of time. For instance, researchers frequently measure financial performance yearly, which is unlikely to reflect the impact of CSR investments, as this requires a longer time. Despite our non-quantitative approach, our findings show that that CSR contributes to shareholder value. For instance, it helps to preserve the environment from ruins that grant the opportunity/licence for the firm to continue to operate. Also, an organisation that exploits workers may lose access to valuable employees in the future. With this thinking, one can expect a significant focus on CSR to evolve naturally and be sustained in corporations. This opportunity will allow future researchers to explore how CSR enables organisations to account for their externalities within a shareholder value maximisation mindset.

\section{References}

Adegbite, E. (2012), "Corporate governance in the Nigerian banking industry: towards governmental engagement". International Journal of Business Governance and Ethics, Vol. 7 No 3, pp. 209-231.

Adegbite, E. (2012), "Corporate governance regulation in Nigeria". Corporate Governance: The International Journal of Business in Society, Vol. 12 No 2, pp. 257-276.

Adegbite, E. (2015), "Good corporate governance in Nigeria: Antecedents, propositions and peculiarities". International Business Review, Vol. 24 No 2, pp. 319-330.

Adegbite, E., Guney, Y., Kwabi, F. and Tahir, S. (2019), "Financial and corporate social performance in the UK listed firms: the relevance of non-linearity and lag effects". Review of Quantitative Finance and Accounting, Vol. 52 No 1, pp. 105-158.

Adegbite, E. and Nakajima, C. (2011), "Corporate governance and responsibility in Nigeria". International Journal of Disclosure and Governance, Vol. 8 No 3, pp. 252-271.

Adegbite, E., Shrives, P. and Nichol, T. (2011), "The role of government in corporate governance: perspectives from the UK". Corporate Ownership and Control, Vol. 9 No 1, pp. 283-293.

Agrawal, A. and Hockerts, K. (2019), "Impact investing: review and research agenda". Journal of Small Business \& Entrepreneurship, pp. 1-29.

Agyei-Mensah, B. K. (2017), "The relationship between corporate governance, corruption and forward-looking information disclosure: a comparative study". Corporate Governance: The International Journal of Business in Society, Vol. 17 No 2, pp. 284-304. 
Albareda, L. (2008), "Corporate responsibility, governance and accountability: from selfregulation to co-regulation". Corporate Governance: The International Journal of Business in Society, Vol. 8 No 4, pp. 430-439.

Amaeshi, K. (2010), "Different markets for different folks: Exploring the challenges of mainstreaming responsible investment practices". Journal of Business Ethics, Vol. 92 No 1, pp. 41-56.

Amaeshi, K., Adegbite, E. and Rajwani, T. (2016), "Corporate Social Responsibility in challenging and non-enabling institutional contexts: do institutional voids matter?". Journal of Business Ethics, Vol. 134 No 1, pp. 135-153.

Amaeshi, K., Nnodim, P. and Osuji, O. K. (2013), Corporate Social Responsibility, Entrepreneurship, and Innovation, Routledge, New York, NY.

Archel, P., Husillos, J. and Spence, C. (2011), "The institutionalisation of unaccountability: Loading the dice of Corporate Social Responsibility discourse". Accounting, Organizations and Society, Vol. 36 No 6, pp. 327-343.

Baden, D. and Harwood, I. A. (2013), "Terminology matters: A critical exploration of corporate social responsibility terms". Journal of Business Ethics, Vol. 116 No 3, pp. 615627.

Bakan, J. (2004), The Corporation: The Pathological Pursuit of Profit and Power, Free Press, New York, NY.

Bakre, O. M. (2007), "The unethical practices of Accountants and Auditors and the compromising stance of professional bodies in the corporate world: Evidence from corporate Nigeria". Accounting Forum, Vol. 31 No 3, pp. 277-303.

Banerjee, S. B. (2009), Corporate Social Responsibility: The Good, the Bad and the Ugly, Edward Elgar Publishing Ltd, Cheltenham, UK.

Banyi, M., Caplan, D. and Graham, R. (2011), "The short happy life of Celiant Corporation: Did managerialism at Lucent Technologies divert shareholder wealth to private equity investors?". Critical Perspectives on Accounting, Vol. 22 No 4, pp. 337-350.

Bell, E., Bryman, A. and Harley, B. (2015), Business Research Methods, Oxford University Press, Oxford, UK.

Boltanski, L. and Chiapello, E. (2001), "The role of critique in the dynamics of new capitalism and the normative change". Berliner Journal Fur Soziologie, Vol. 11 No 4, pp. 459-477.

Boltanski, L. and Chiapello, E. (2005), "The new spirit of capitalism". International Journal of Politics, Culture, and Society, Vol. 18 No 3-4, pp. 161-188.

Bondy, K. (2008), "The paradox of power in CSR: A case study on implementation". Journal of Business Ethics, Vol. 82 No 2, pp. 307-323.

Bonin, J. P., Hasan, I. and Wachtel, P. (2005), "Bank performance, efficiency and ownership in transition countries". Journal of Banking \& Finance, Vol. 29 No 1, pp. 31-53. 
Campbell, J. L. (2007), "Why would corporations behave in socially responsible ways? An institutional theory of corporate social responsibility". Academy of Management Review, Vol. 32 No 3, pp. 946-967.

Chen, T., Dong, H. and Lin, C. (2020), "Institutional shareholders and corporate social responsibility". Journal of Financial Economics, Vol. 135 No 2, pp. 483-504.

Chen, Y.-C., Hung, M. and Wang, Y. (2018), "The effect of mandatory CSR disclosure on firm profitability and social externalities: Evidence from China". Journal of Accounting and Economics, Vol. 65 No 1, pp. 169-190.

Chiapello, E. (2007), "Accounting and the birth of the notion of capitalism". Critical Perspectives on Accounting, Vol. 18 No 3, pp. 263-296.

Chiu, S.-C. and Sharfman, M. (2011), "Legitimacy, visibility, and the antecedents of corporate social performance: An investigation of the instrumental perspective". Journal of Management, Vol. 37 No 6, pp. 1558-1585.

Cooper, D. J. and Morgan, W. (2008), "Case study research in accounting". Accounting Horizons, Vol. 22 No 2, pp. 159-178.

Crane, B. (2020), "Revisiting who, when, and why stakeholders matter: Trust and stakeholder connectedness". Business \& Society, Vol. 59 No 2, pp. 263-286.

Crouch, C. (2006), "Modelling the firm in its market and organizational environment: Methodologies for studying corporate social responsibility". Organization Studies, Vol. 27 No 10, pp. 1533-1551.

Crouch, C. (2008), "What will follow the demise of privatised Keynesianism?". The Political Quarterly, Vol. 79 No 4, pp. 476-487.

Crouch, C. (2009), "Privatised Keynesianism: An unacknowledged policy regime". The British Journal of Politics and International Relations, Vol. 11 No 3, pp. 382-399.

Cuervo-Cazurra, A. (2018), "The evolution of business groups' corporate social responsibility". Journal of Business Ethics, Vol. 153 No 4, pp. 997-1016.

Cui, J., Jo, H. and Na, H. (2018), "Does corporate social responsibility affect information asymmetry?". Journal of Business Ethics, Vol. 148 No 3, pp. 549-572.

Daudigeos, T. and Valiorgue, B. (2011), "Conditions for value creation in the marketplace through the management of CSR issues: A negative external effects framework". Business \& Society, Vol. 50 No 1, pp. 28-49.

Davies, P. L. (2002), Clarendon Law Series, Oxford University Press, Oxford, UK.

Deephouse, D. L. and Jaskiewicz, P. (2013), "Do family firms have better reputations than non-family firms? An integration of socioemotional wealth and social identity theories". Journal of Management Studies, Vol. 50 No 3, pp. 337-360.

Delgado-García, J. B., De Quevedo-Puente, E. and De La Fuente-Sabaté, J. M. (2010), "The impact of ownership structure on corporate reputation: Evidence from Spain". Corporate Governance: An International Review, Vol. 18 No 6, pp. 540-556. 
Eisenhardt, K. M. (1989), "Building theories from case study research". Academy of Management Review, Vol. 14 No 4, pp. 532-550.

European Commission. (2011), “A renewed EU strategy 2011-14 for corporate social responsibility", available at: https://eur-lex.europa.eu/legalcontent/EN/TXT/PDF/?uri=CELEX:52011DC0681\&from=EN (accessed 11 September 2019).

Ewings, P., Powell, R., Barton, A. and Pritchard, C. (2008), Qualitative Research Methods, Peninsula Research and Development Support Unit, Plymouth, UK.

Fama, E. F. (1980), "Agency problems and the theory of the firm". The Journal of Political Economy, Vol. 88 No 2, pp. 288-307.

Fama, E. F. and Jensen, M. C. (1983), "Separation of ownership and control". Journal of Law and Economics, Vol. 26 No 2, pp. 301-325.

Fassin, Y. (2008), "Imperfections and shortcomings of the stakeholder model's graphical representation". Journal of Business Ethics, Vol. 80 No 4, pp. 879-888.

Fidelity Bank. (2014), “Corporate social responsibility", available at: https://csr.fidelitybank.ng/, (accessed 3 March 2019).

Flyvbjerg, B. (2006), "Five misunderstandings about case-study research". Qualitative inquiry, Vol. 12 No 2, pp. 219-245.

Freeman, R. E. (1984), Strategic Management: A Stakeholder Approach, Pitman, Cambridge, $\mathrm{UK}$,

Freeman, R. E., Phillips, R. and Sisodia, R. (2020), "Tensions in stakeholder theory". Business \& Society, Vol. 59 No 2, pp. 213-231.

Gallhofer, S. and Haslam, J. (1993), "Approaching corporate accountability: fragments from the past". Accounting and Business Research, Vol. 23 No 1, pp. 320-330.

Galunic, C., Ertug, G. and Gargiulo, M. (2012), "The positive externalities of social capital: Benefiting from senior brokers". Academy of Management Journal, Vol. 55 No 5, pp. 12131231.

Gaya, H. and Smith, E. (2016), "Developing a qualitative single case study in the strategic management realm: An appropriate research design". International Journal of Business Management and Economic Research, Vol. 7 No 2, pp. 529-538.

Gibbert, M. (2006), "Munchausen, black swans, and the RBV: Response to Levitas and Ndofor". Journal of Management Inquiry, Vol. 15 No 2, pp. 145-151.

Global Reporting Initiative. (2013). G4 Sector Disclosures: Financial Services. Global Reporting Initiative, The Netherlands.

Hahn, T., Pinkse, J., Preuss, L. and Figge, F. (2016), "Ambidexterity for corporate social performance". Organization Studies, Vol. 37 No 2, pp. 213-235.

Hawn, O. (2009), "Corporate Social Responsibility in the international context: When and does it matter?". European Management Review, Vol. 6 No 3, pp. 206-206. 
Healy, P. M. and Palepu, K. G. (2001), "Information asymmetry, corporate disclosure, and the capital markets: A review of the empirical disclosure literature". Journal of Accounting and Economics, Vol. 31 No 1, pp. 405-440.

Heflin, F. and Wallace, D. (2017), "The BP oil spill: shareholder wealth effects and environmental disclosures". Journal of Business Finance and Accounting, Vol. 44 No 3-4, pp. 337-374.

Hendry, J., Sanderson, P., Barker, R. and Roberts, J. (2007), "Responsible ownership, shareholder value and the new shareholder activism". Competition \& Change, Vol. 11 No 3, pp. 223-240.

Herzig, C. and Moon, J. (2013), "Discourses on corporate social ir/responsibility in the financial sector". Journal of Business Research, Vol. 66 No 10, pp. 1870-1880.

Hughes, L. C. and Preski, S. (1997), "Using key informant methods in organizational survey research: Assessing for informant bias". Research in Nursing \& Health, Vol. 20 No 1, pp. 8192.

Iannotta, G., Nocera, G. and Sironi, A. (2007), "Ownership structure, risk and performance in the European banking industry". Journal of Banking \& Finance, Vol. 31 No 7, pp. 21272149 .

International Monetary Fund. (2013), "Nigeria: Financial sector stability assessment". IMF Country Report, Vol. 13 No 140.

Ireland, P. (2005), "Shareholder primacy and the distribution of wealth". The Modern Law Review, Vol. 68 No 1, pp. 49-81.

Jamali, D. (2008), "A stakeholder approach to corporate social responsibility: a fresh perspective into theory and practice". Journal of Business Ethics, Vol. 82 No 1, pp. 213-231.

Jamali, D. and Karam, C. (2018), "Corporate social responsibility in developing countries as an emerging field of study". International Journal of Management Reviews, Vol. 20 No 1, pp. $32-61$.

Jensen, M. C. (2001), "Value maximization, stakeholder theory, and the corporate objective function". Journal of Applied Corporate Finance, Vol. 14 No 3, pp. 8-21.

Jensen, M. C. and Meckling, W. H. (1976), "Theory of the firm: managerial behavior, agency costs and ownership structure". Journal of Financial Economics, Vol. 3 No 4, pp. 305-360.

Jensen, M. C. and Warner, J. B. (1988), "The distribution of power among corporate managers, shareholders, and directors". Journal of Financial Economics, Vol. 20 JanuaryMarch, pp. 3-24.

Johnston, A., Amaeshi, K., Adegbite, E. and Osuji, O. (2019), "Corporate social responsibility as obligated internalisation of social costs". Journal of Business Ethics, pp. 114.

Kaler, J. (2003), "Differentiating stakeholder theories". Journal of Business Ethics, Vol. 46 No 1, pp. 71-83. 
Kanter, R. M. (2011), "How great companies think differently". Harvard Business Review, Vol. 89 No 11, pp. 64-80.

Kaufmann, D., Kraay, A. and Mastruzzi, M. (2009), "Governance matters VIII: aggregate and individual indicators, 1996-2008". World Bank Policy Research Paper, Vol. 4978.

Kelly, M. (2001), The Divine Right of Capital: Dethroning the Corporate Aristocracy, Berrett-Koehler Publishers, San Francisco, CA.

Kemper, A. and Martin, R. L. (2010), "After the fall: The global financial crisis as a test of corporate social responsibility theories". European Management Review, Vol. 7 No 4, pp. 229-239.

Kramer, M. (2012), "What is wrong with maximizing shareholder wealth"? available at: http://www.guardian.co.uk/sustainable-business/blog/maximising-shareholder-valueirony?intcmp=122andCMP $=$ (accessed 23 July 2019).

Laibman, D. (2002), "Value and the quest for the core of capitalism". Review of Radical Political Economics, Vol. 34 No 2, pp. 159-178.

Lange, D. and Washburn, N. T. (2012), "Understanding attributions of corporate social irresponsibility". Academy of Management Review, Vol. 37 No 2, pp. 300-326.

Langtry, B. (1994), "Stakeholders and the moral responsibilities of business". Business Ethics Quarterly, Vol. 4 No 4, pp. 431-443.

Lauesen, L. M. (2013), "CSR in the aftermath of the financial crisis". Social Responsibility Journal, Vol. 9 No 4, pp. 641-663.

Lazonick, W. (2010), "Innovative business models and varieties of capitalism:

Financialization of the US corporation". Business History Review, Vol. 84 No 4, pp. 675-702.

Levy, D. L. and Newell, P. (2006). "Multinationals in Global Governance". in Vachani, S. (Ed.), Transformations in Global Governance: Implications for Multinationals and Other Stakeholders. Edward Elgar, London, UK, pp. 146-167.

Lynn, P., Smith, P. and Turner, R. (1998), "Assessing the effects of an advance letter for a personal interview survey". International Journal of Market Research, Vol. 40 No 3, pp. 265272.

Macey, J. and O'hara, M. (2003), "The corporate governance of Banks". FRBNY Economic Policy Review, Vol. 9 No 1, pp. 91-107.

Mahon, J. F. (2002), "Corporate reputation: Research agenda using strategy and stakeholder literature". Business \& Society, Vol. 41 No 4, pp. 415-445.

Mallin, C. A. and Michelon, G. (2011), "Board reputation attributes and corporate social performance: An empirical investigation of the US best corporate citizens". Accounting and Business Research, Vol. 41 No 2, pp. 119-144.

Marx, K. (1867), Capital: A Critique of Political Economy, Progress Publishers, Moscow, Russia. 
Mcwilliams, A. and Siegel, D. (2001), "Corporate social responsibility: A theory of the firm perspective". Academy of Management Review, Vol. 26 No 1, pp. 117-127.

Miller, C. C., Cardinal, L. B. and Glick, W. H. (1997), "Retrospective reports in organizational research: A reexamination of recent evidence". Academy of Management Journal, Vol. 40 No 1, pp. 189-204.

Mishkin, F. (2011), "Over the cliff: From the subprime to the global financial crisis". Journal of Economic Perspectives, Vol. 25 No 1, pp. 49-70.

Moir, L. (2001), "What do we mean by corporate social responsibility?". Corporate Governance: The International Journal of Business in Society, Vol. 1 No 2, pp. 16-22.

Moore, G. (1999), "Tinged shareholder theory: or what's so special about stakeholders?". Business Ethics: A European Review, Vol. 8 No 2, pp. 117-127.

Nakpodia, F. and Adegbite, E. (2018), "Corporate governance and elites". Accounting Forum, Vol. 42 No 1, pp. 17-31.

Nakpodia, F., Adegbite, E., Amaeshi, K. and Owolabi, A. (2018), "Neither principles nor rules: making corporate governance work in Sub-Saharan Africa.". Journal of Business Ethics, Vol. 151 No 2, pp. 391-408.

Nakpodia, F., Shrives, P. and Sorour, K. (2018), "Examining the link between religion and corporate governance: Insights from Nigeria". Business \& Society, pp. 1-39.

Okike, E., Adegbite, E. A., Nakpodia, F. A. and Adegbite, S. (2015), "A review of internal and external influences on corporate governance and financial accountability in Nigeria". International Journal of Business Governance and Ethics, Vol. 10 No 2, pp. 165-185.

Okpara, J. (2011), "Corporate governance in a developing economy: barriers, issues, and implications for firms". Corporate Governance: The International Journal of Business in Society, Vol. 11 No 2, pp. 184-199.

Page, A. and Katz, R. (2012), "The truth about Ben and Jerry's", available at: https://ssir.org/articles/entry/the truth about ben and jerrys (accessed 16 June 2019).

Payne, R. L. and Mansfield, R. (1973), "Relationships of perceptions of organizational climate to organizational structure, context, and hierarchical position". Administrative Science Quarterly, Vol. 18 No 4, pp. 515-526.

Polanyi, K. (1944), The Great Transformation: The Political and Economic Origins of Our Time, Beacon Press, Boston, MA.

Queen, P. E. (2015), "Enlightened shareholder maximization: is this strategy achievable?". Journal of Business Ethics, Vol. 127 No 3, pp. 683-694.

Rao, K. K., Tilt, C. A. and Lester, L. H. (2012), "Corporate governance and environmental reporting: an Australian study". Corporate Governance: The International Journal of Business in Society, Vol. 12 No 2, pp. 143-163.

Ringov, D. and Zollo, M. (2007), "The impact of national culture on corporate social performance". Corporate Governance: The International Journal of Business in Society, Vol. 7 No 4, pp. 476-485. 
Saunders, M. N. K., Lewis, P. and Thornhill, A. (2015), Research Methods for Business Students, Pearson, New York, NY.

Seny Kan, K.A., Apitsa, S.M. and Adegbite, E. (2015), "African management: concept, content and usability", Society and Business Review, Vol.10 No 3, pp. 258-279.

Sharfman, B. S. (2014), "Shareholder wealth maximization and its implementation under corporate law". Florida Law Review, Vol. 66 No 1, pp. 389-431.

Sison, A. J. G. (2007), "Toward a common good theory of the firm: The Tasubinsa case". Journal of Business Ethics, Vol. 74 No 4, pp. 471-480.

Solomon, J. F. and Darby, L. (2005), "Is private social, ethical and environmental reporting mythicizing or demythologizing reality?". Accounting Forum, Vol. 29 No 1, pp. 27-47.

Stanton-Ife, J. (20008), "The limits of law". Stanford Encyclopedia of Philosophy, Vol. Fall No 1, pp. 1-20.

Stiglitz, J. E. (2002), Globalization and its Discontents, Norton, New York, NY.

Stout, L. A. (2012), The Shareholder Value Myth: How Putting Shareholders First Harms Investors, Corporations, and the Public, Berrett-Koehler Publishers, San Francisco, CA.

Sweetin, V. H., Knowles, L. L., Summey, J. H. and Mcqueen, K. S. (2013), "Willingness-topunish the corporate brand for corporate social irresponsibility". Journal of Business Research, Vol. 66 No 10, pp. 1822-1830.

The Economist. (2010b), "The risk externality", available at: http://www.economist.com/blogs/freeexchange/2010/01/risk externality (accessed 26 January 2019).

The Economist. (2010a), "Shareholders vs. stakeholders: a new idolatry", available at: http://www.economist.com/node/15954434 (accessed 29 April 2019).

Tirole, J. (2010), The Theory of Corporate Finance, Princeton University Press, Princeton, NJ.

Toppinen, A. and Korhonen-Kurki, K. (2013), "Global Reporting Initiative and social impact in managing corporate responsibility: a case study of three multinationals in the forest industry". Business Ethics: A European Review, Vol. 22 No 2, pp. 202-217.

Uche, C., Adegbite, E. and Jones, M. (2016), "Institutional shareholder activism in Nigeria: An accountability perspective", Accounting Forum, Vol.40 No 2, pp. 78-88.

Udayasankar, K. (2008), "Corporate social responsibility and firm size". Journal of Business Ethics, Vol. 83 No 2, pp. 167-175.

Unerman, J., Bebbington, J. and O'dwyer, B. (2018), "Corporate reporting and accounting for externalities". Accounting and Business Research, Vol. 48 No 5, pp. 497-522.

von Kriegstein, H. (2016), "Professionalism, agency, and market failures". Business Ethics Quarterly, Vol. 26 No 4, pp. 445-464.

Windsor, D. (2006), "Corporate social responsibility: Three key approaches". Journal of Management Studies, Vol. 43 No 1, pp. 93-114. 
Yekini, K. C., Adelopo, I. and Adegbite, E. (2017), "The impact of community expectations on corporate community involvement disclosures in the UK". Accounting Forum, Vol. 41 No 3, pp. 234-252.

Yin, R. K. (2014), Case Study Research: Design and Methods (Applied Social Research Methods), Sage Publications, Thousand Oaks, CA.

\section{Acknowledgments}

The authors are grateful for the research funding received from The British Academy for this project. The authors also thank Fidelity Bank, Nigeria, for the data access granted. 


\section{FIGURES}

\section{Figure 1: Conventional shareholder model without regards to positive and negative} externalities

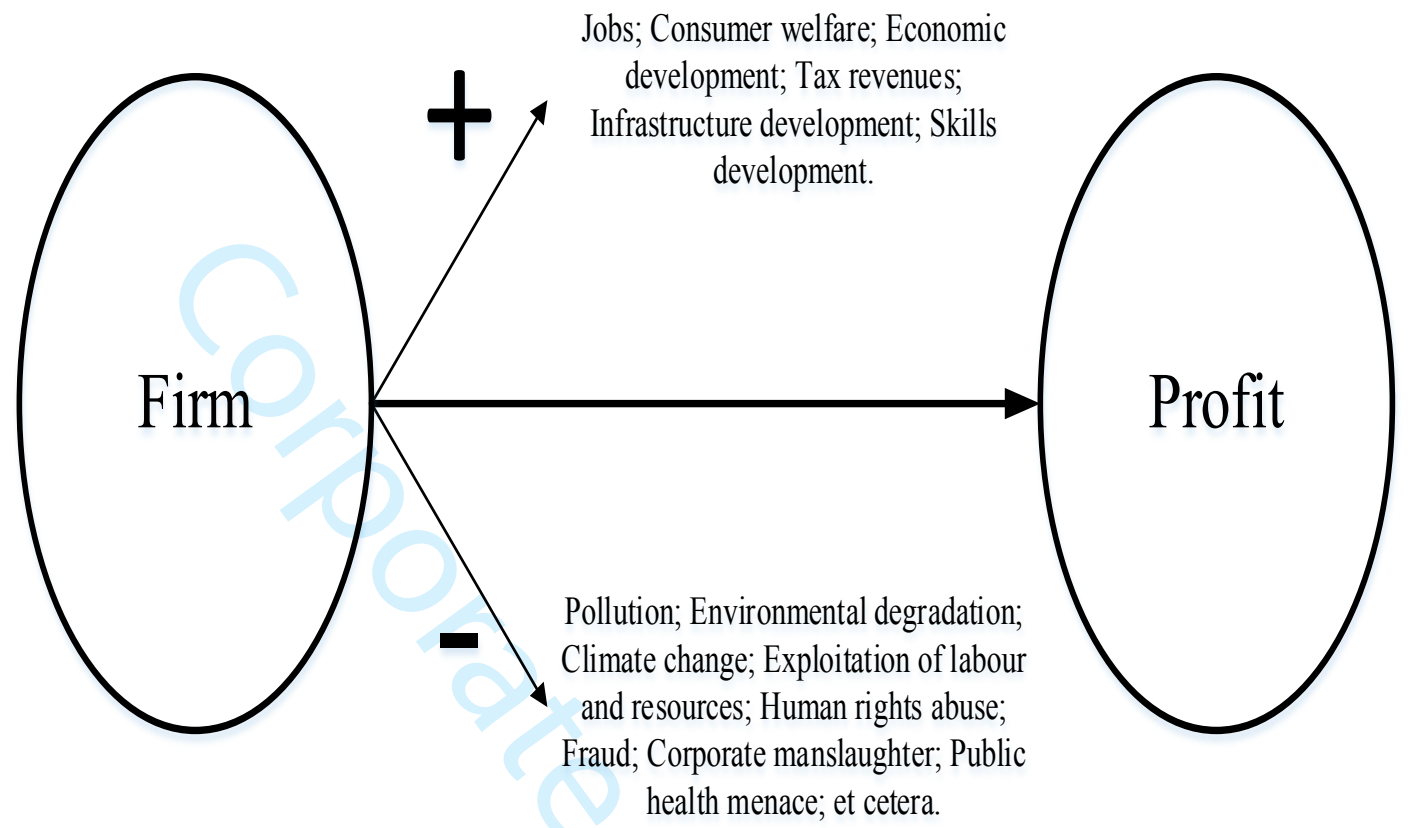

Figure 2: CSR as a Governance Mechanism of Externalities

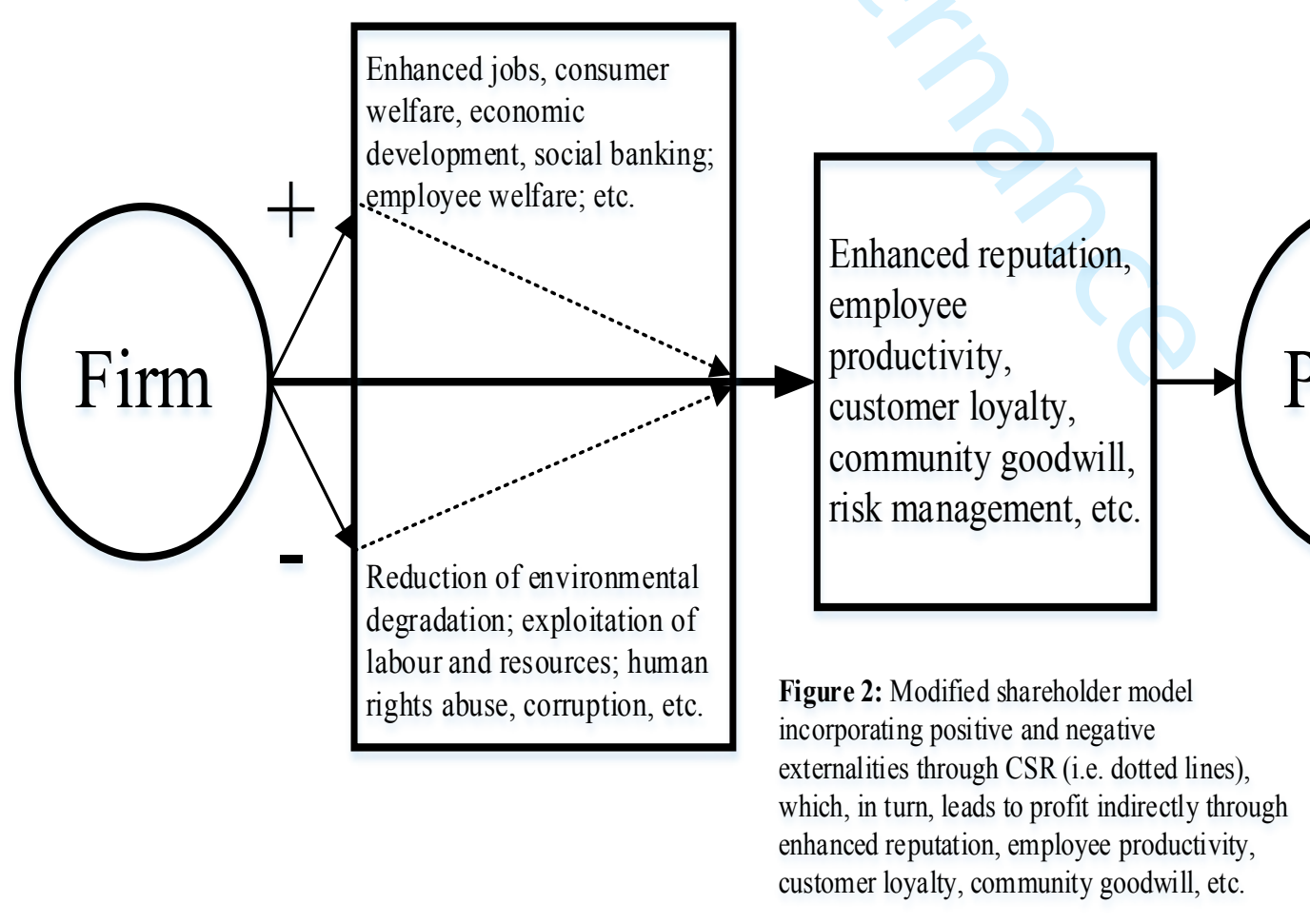




\section{TABLE}

Table 1 Reconciling Shareholder Value and Corporate Externalities through Corporate Social
Responsibility

\begin{tabular}{|c|c|c|c|c|}
\hline $\begin{array}{l}\text { CSR } \\
\text { Practic } \\
\text { e/Class } \\
\text { ificatio } \\
\text { n }\end{array}$ & $\begin{array}{l}\text { CSR } \\
\text { Activities }\end{array}$ & $\begin{array}{l}\text { Externaliti } \\
\text { es } \\
\text { (preventing } \\
\text { negative/cr } \\
\text { eating } \\
\text { positive) }\end{array}$ & $\begin{array}{l}\text { Data extracts (linking CSR - preventing } \\
\text { externalities - promoting shareholder } \\
\text { value) }\end{array}$ & $\begin{array}{l}\text { Implicatio } \\
\text { ns for } \\
\text { Sharehold } \\
\text { er value }\end{array}$ \\
\hline $\begin{array}{l}\text { CSR in } \\
\text { the } \\
\text { Econo } \\
\text { my }\end{array}$ & $\begin{array}{l}\text { Inclusive } \\
\text { financial } \\
\text { strategy } \\
\text { (product } \\
\text { responsibility } \\
\text { ) } \\
\text { Less } \\
\text { profitable } \\
\text { lending }\end{array}$ & $\begin{array}{l}\text { Poverty } \\
\text { reduction } \\
\text { Economic } \\
\text { Growth/Incr } \\
\text { eased } \\
\text { productivity } \\
\text { in the real } \\
\text { economy } \\
\text { Job } \\
\text { creation/pov } \\
\text { erty } \\
\text { reduction }\end{array}$ & $\begin{array}{l}\text { "We engage the unbanked people" } \\
\text { (Interview with CSR ambassador) "We also } \\
\text { went as far as doing social banking" (Focus } \\
\text { group participant) } \\
\text { "...the focus of the government then was to } \\
\text { stop rice importation, so the bank partnered } \\
\text { with the rice farm to get it to run smoothly } \\
\text { through loans which are not excruciating to } \\
\text { help their production capacity" (Focus } \\
\text { group participant) } \\
\text { "We also give them (new graduates) project } \\
\text { financing ... some of them have started } \\
\text { businesses. We create entrepreneurs, and } \\
\text { we create jobs. We also help them in terms } \\
\text { of their business idea, sourcing for } \\
\text { resources, including funds, training and } \\
\text { development." (Focus group participant) }\end{array}$ & $\begin{array}{l}\begin{array}{l}\text { More } \\
\text { customers }\end{array} \\
\text { A } \\
\text { productive } \\
\text { economy }\end{array}$ \\
\hline $\begin{array}{l}\text { CSR in } \\
\text { the } \\
\text { Social } \\
\text { System }\end{array}$ & $\begin{array}{l}\text { Helping } \\
\text { Hands } \\
\text { programme } \\
\text { (including }\end{array}$ & $\begin{array}{l}\text { Internalisin } \\
\mathrm{g} \text { harm } \\
\text { (stress) to } \\
\text { employees } \\
\text { Promoting } \\
\text { the health of } \\
\text { employees } \\
\text { Humanitaria } \\
\mathrm{n} \text { assistance } \\
\text { to the hard } \\
\text { to reach }\end{array}$ & $\begin{array}{l}\text { "even though there is a policy that you don't } \\
\text { get paid if you get pregnant when you just } \\
\text { join a company, we relax such rules here to } \\
\text { promote family life balance" (Focus group } \\
\text { participant) } \\
\text { "We stick to normal working hours ...We } \\
\text { improve the health of our staff. ... } \\
\text { deliberate ... internalising a ... third party } \\
\text { cost to ... our employees. (Interview with a } \\
\text { CSR ambassador). "We make employees } \\
\text { happy... we have created a healthy work } \\
\text { environment ... Stakeholders' happiness is } \\
\ldots \text { shareholders happiness" (Interview with } \\
\text { CSR ambassador) } \\
\text { "We go to motherless babies } \\
\text { homes...government hospitals. We don't } \\
\text { go the prosperous areas ...we go to the }\end{array}$ & $\begin{array}{l}\text { More } \\
\text { productive } \\
\text { employees } \\
\text { Committe } \\
\text { d } \\
\text { employees }\end{array}$ \\
\hline
\end{tabular}




\begin{tabular}{|c|c|c|c|c|}
\hline $\begin{array}{l}\text { CSR } \\
\text { Practic } \\
\text { e/Class } \\
\text { ificatio } \\
\text { n }\end{array}$ & $\begin{array}{l}\text { CSR } \\
\text { Activities }\end{array}$ & $\begin{array}{l}\text { Externaliti } \\
\text { es } \\
\text { (preventing } \\
\text { negative/cr } \\
\text { eating } \\
\text { positive) }\end{array}$ & $\begin{array}{l}\text { Data extracts (linking CSR - preventing } \\
\text { externalities - promoting shareholder } \\
\text { value) }\end{array}$ & $\begin{array}{l}\text { Implicatio } \\
\text { ns for } \\
\text { Sharehold } \\
\text { er value }\end{array}$ \\
\hline & $\begin{array}{l}\text { Education, } \\
\text { Health care } \\
\text { and } \\
\text { philanthropic } \\
\text { interventions) }\end{array}$ & & $\begin{array}{l}\text { downtrodden communities" (Focus group } \\
\text { participant) } \\
\text { "We get goodwill from our CSR activities." } \\
\text { (Focus group participant). "CSR...is } \\
\text { good for our corporate image." (Head of } \\
\text { CSR) } \\
\text { "If you don't say thank you by doing CSR, } \\
\text {... it may affect your business in the future" } \\
\text { (Focus group participant). "The } \\
\text { shareholders are happy ... We have their } \\
100 \text { per cent support" (Focus group } \\
\text { participant) } \\
\text { "Every day you hear banks being attacked } \\
\text { in Nigeria, but Fidelity bank is never } \\
\text { attacked, it is because of the goodwill we } \\
\text { receive from our CSR" (Focus group } \\
\text { participant) }\end{array}$ & $\begin{array}{l}\text { Publicity } \\
\text { gains } \\
\text { Doing well } \\
\text { by doing } \\
\text { good } \\
\text { Risk } \\
\text { manageme } \\
\text { nt }\end{array}$ \\
\hline $\begin{array}{l}\text { CSR in } \\
\text { the } \\
\text { enviro } \\
\text { nment }\end{array}$ & $\begin{array}{l}\text { Use of } \\
\text { biodegradabl } \\
\text { e bags } \\
\text { Switching off } \\
\text { the generator } \\
\text { at 6pm and } \\
\text { Mass } \\
\text { Transportatio } \\
n \text { services }\end{array}$ & $\begin{array}{l}\text { Preventing } \\
\text { harm to the } \\
\text { environmen } \\
\mathrm{t}\end{array}$ & $\begin{array}{l}\text { "We use biodegradable bags, thus helping } \\
\text { the ecosystem.... Others are now doing the } \\
\text { same" (Head of CSR) } \\
\text { "By switching our generators off, we reduce } \\
\text { our carbon emission" (Interview with a } \\
\text { CSR ambassador) "We have over } 23 \text { staff } \\
\text { buses to provide transport; my colleagues in } \\
\text { other banks are so envious of these". (Head } \\
\text { of CSR). }\end{array}$ & $\begin{array}{l}\text { Reputation } \\
\text { as } \\
\text { pacesetter/ } \\
\text { Loyal } \\
\text { customers } \\
\\
\text { Loyal } \\
\text { employees }\end{array}$ \\
\hline
\end{tabular}

